\title{
Monitoring Deformasi Gunung Merapi Menggunakan Citra Sentinel-1A Dengan Menggunakan Metode DInSAR (Studi Kasus: Gunung Merapi, Jawa Tengah)
}

\author{
Rian Nurtyawan, Lady Suci Utami \\ Jurusan Teknik Geodesi, Fakultas Teknik Sipil dan Perencanaan, ITENAS, Bandung \\ Email: nurtyawan70@gmail.com
}

Received 28 Maret 2020 | Revised 14 April 2020 | Accepted 12 May 2020

\begin{abstract}
ABSTRAK
Indonesia mempunyai 127 gunung api aktif yang tersebar dari Sabang sampai Merauke. Oleh karena itu, perlu adanya pemantauan aktivitas gunung api yang dapat digunakan untuk acuan mitigasi bencana. Pada penelitian ini menggunakan metode deformasi, metode deformasi merupakan perubahan bentuk, posisi, dan dimensi dari suatu benda. Tujuan dari pemantauan deformasi ini untuk mengetahui perubahan gunung api yang disebabkan oleh aktivitas gunung api. Pemantauan aktivitas gunung api metode deformasi dilakukan dengan menggunakan citra Sentinel-1A yang diolah dengan teknologi Differential Interferometry SAR (DInSAR). Dalam penelitian ini dilakukan pengolahan dengan teknologi DInSAR metode two-pass dari empat buah citra satelit sentinel-1A 10 Januari 2018, 27 Februari 2018, 10 Mei 2018 dan 22 Januari 2019 serta data Digital Elevation Model (DEM) SRTM dengan ketelitian 30 meter. Hasil dari penelitian ini yaitu peta deformasi pra 1 erupsi yang diolah dari pasangan citra 10 Januari 2018 dengan citra 27 Februari 2018 yang menghasilkan deflasi sebesar -0,12 meter, dan peta deformasi pra 2 erupsi yang diolah dari pasangan citra 27 Februari 2018 dan 10 Mei 2018 menghasilkan deflasi sebesar -0,27 meter serta peta pasca erupsi yang diolah dari pasangan citra 10 Mei 3018 dan 22 Januari 2019 menghasilkan deflasi sebesar -0,194 meter.
\end{abstract}

Kata kunci: Deformasi, Gunung Merapi, Sentinel-1A, DInSAR.

\begin{abstract}
Indonesia has 127 active volcanoes spread over from Sabang to Merauke. Therefore, it is necessary to monitor volcanic activity that can be used as a reference for disaster mitigation. In this study, deformation method was used to reflect a change in the shape, position, and dimensions of an object. The purpose of monitoring this deformation is to find out volcanic changes caused by volcanic activity. Monitoring the volcanic activity of the deformation method is carried out using Sentinel-1A images processed with Differential Interferometry SAR (DInSAR) technology. In this research, two-pass method of DInSAR technology was processed using four sentinel-1A satellite images on January 10, 2018, February 27, 2018, May 10, 2018 and January 22, 2019 and SRTM Digital Elevation Model (DEM) data with 30 meters accuracy. This research processed pre-eruption deformation map from the 10 January 2018 imagery pair with the 27 February 2018 image which resulted in a deflation of 0.12 meters. Preeruption 2 deformation map was processed from the 27 February 2018 and 10 May 2018 image pairs and resulted in a deflation of 0.27 meters while post-eruption map processed from the 10 May 3018 and 22 January 2019 image pairs resulted in deflation of 0.194 meters.
\end{abstract}

Keywords: Deformation, Merapi Mountain, Sentinel-1A, DinSAR. 


\section{PENDAHULUAN}

Menurut [1] Indonesia memiliki 127 gunung api aktif yang tersebar dari Sabang sampai Merauke. Indonesia merupakan negara yang memiliki gunung api terbanyak di dunia, oleh karena itu perlu adanya pemantauan aktivitas gunung api yang dapat digunakan untuk acuan mitigasi bencana, terutama gunung api yang termasuk dengan gunung api kota. Gunung api kota merupakan gunung api yang memiliki letak di perkotaan sehingga memiliki aktivitas manusia yang tinggi dan memiliki perkiraan korban yang banyak pula.

Salah satu gunung api yang masih aktif yaitu Gunung Merapi yang berada di Jawa Tengah. Terdapat beberapa metode yang digunakan untuk mengetahui aktivitas gunung berapi yaitu metode seismik, metode deformasi, metode kimia gas, metode termal. Namun pada penelitian ini metode yang digunakan yaitu metode deformasi. Menurut [2] metode deformasi saat ini sudah mulai banyak diterapkan untuk mengetahui aktivitas gunung api, metode deformasi dapat diterapkan menggunakan berbagai macam sensor atau sistem. Sejak meletus pada tahun 2010, Gunung Merapi di Jawa Tengah telah mengalami deformasi yang begitu cepat. Menurut [1] pada tahun 2011, magma letusan Gunung Merapi terdeteksi sudah mulai mengisi kembali kantung - kantung magma di bawah Gunung Merapi.

Deformasi adalah perubahan posisi, bentuk dan ukuran materi [3]. Berdasarkan definisi tersebut deformasi dapat diartikan sebagai perubahan kedudukan atau pergerakan suatu titik pada suatu benda secara absolut apabila dikaji dari perilaku gerakan titik itu sendiri maupun relatif apabila gerakan dikaji dari titik yang lain. Metode yang digunakan untuk mengamati aktivitas Gunung Merapi pada penelitian ini yaitu metode deformasi sistem pengindraan jauh yang menggunakan data citra yang kemudian diolah menggunakan metode DInSAR. DInSAR adalah teknik akuisisi dua citra Synthetic Aperture Radar (SAR) berpasangan kombinasi data citra kompleks pada posisi spasial yang sama (differential SAR) atau posisinya sedikit berbeda (terrain height InSAR) pada area sama dengan melakukan perkalian konjugasi berganda. Hasil akhir berupa model elevasi digital (DEM) atau pergeseran suatu permukaan bumi [4]. Salah satu citra satelit yang bisa digunakan dalam teknik DInSAR adalah citra satelit Sentinel-1A.

Dalam 25 tahun terakhir, pemetaan dan pemantauan fenomena geohazard telah menerima kontribusi penting dari teknik DInSAR. Pendekatan ini pertama kali diusulkan pada tahun 1989, menggunakan data dari sensor L-band Seasat [5]. Sejak itu, teknik ini mengalami pertumbuhan terus menerus terutama terkait dengan dua komponen utama. Yang pertama adalah upaya penelitian dan pengembangan penting yang dilakukan pada periode ini, yang telah menghasilkan sejumlah besar alat dan metode pengolahan dan analisis data.

Citra satelit Sentinel-1A adalah citra yang dihasilkan oleh satelit Sentinel-1A yang dirancang dan dikembangkan oleh European Space Agency (ESA) pada tahun 2014. Sentinel-1A dapat mengamati muka bumi pada waktu siang dan malam dengan repeat cycle setiap 12 hari. Terdapat empat mode akuisisi yang dipunyai Sentinel-1A yaitu Stripmap (SM), Interferometric Wide Swath (IW), Extra Wide Swath (EW), dan Wave (WV). Pada mode IW citra satelit Sentinel-1A ini memiliki resolusi spasial $5 \mathrm{~m} \times 20 \mathrm{~m}[6]$.

[7] melakukan penelitian tentang analisis deformasi Gunung Raung menggunakan teknologi DInSAR. Pada penelitian ini pengukuran deformasi pada permukaan Gunung Raung dilakukan pengolahan dengan teknologi DInSAR metode two-pass dan three-pass dari tiga buah citra satelit Sentinel-1A bulan Juni 2015, Juli 2015, dan September 2015 serta Digital Elevation Model (DEM) SRTM 30 meter. Penggunaan dua metode ini digunakan untuk membandingkan hasil pengolahan dari kedua metode tersebut jika diterapkan bersamaan apakah memiliki hasil yang sama atau berbeda. Hasil menunjukkan bahwa metode two-pass dan three-pass teknologi DInSAR dapat diterapkan untuk mengetahui deformasi pemukaan Gunung Raung, yang menunjukkan terjadinya deformasi mayoritas ada di kaldera Gunung Raung.

Penelitian ini mengenai monitoring deformasi Gunung Merapi pra 1, pra 2 dan pasca erupsi menggunakan data citra Sentinel 1-A pada tanggal 10 Januari 2018, 27 Februari 2018, 10 Mei 2018 
dan 22 Februari 2019 dengan menggunakan metode DInSAR. Mengkategorikan pra 1, pra 2 dan pasca berguna untuk melihat deformasi secara teliti dan memiliki rentang waktu yang panjang untuk melihat aktivitas Gunung Merapi secara maksimal. Penelitian ini akan menghasilkan peta deformasi yang digunakan untuk melihat aktivitas Gunung Merapi serta rencana penanggulangan Gunung Merapi dan mitigasi bencana yang akan terjadi pada selanjutnya.

\section{METODOLOGI}

Pelaksanaan monitoring deformasi Gunung Merapi menggunakan citra Sentinel 1A dengan Metode Differential Interferometric Synthetic Aperture Radar (DInSAR) terdiri dari dua belas tahapan pekerjaan yang telah ditunjukan pada Gambar 1 yang meliputi pengumpulan data, estimasi baseline, koregistrasi citra, pembuatan interferogram dan estimasi koherensi, top debust, penghapusan fase topografi, filter goldstein, multilooking, subset, phase Unwrapping, konversi fasa ke deformasi dan pengolahan geocoding [8].

\section{HASIL DAN PEMBAHASAN}

Pemantauan aktivitas gunung api melalui metode deformasi dapat diketahui melalui proses monitoring inflasi dan deflasi akibat perubahan tekanan dari dalam gunung api. Pada dasarnya apabila sebuah gunung akan mengalami suatu erupsi maka akan terjadi tekanan magma ke permukaan, sehingga menyebabkan tubuh gunung menjadi mengembang dan adanya kenaikan pada permukaan gunung yang disebut dengan inflasi, sedangkan apabila gunung tersebut sudah mengalami erupsi maka tubuh gunung mengalami penyusutan atau penurunan yang disebut dengan deflasi [7]. Didalam pengolahan menggunakan metode DInSAR, inflasi ditunjukkan dengan tanda plus $(+)$ dan deflasi ditunjukkan dengan tanda minus (-).

Pada penelitian ini yang menjadi acuan penelitian adalah erupsi Gunung Merapi pada tanggal 11 Mei 2018. Oleh karena itu, untuk melihat perubahan dari Gunung Merapi dengan rentang waktu yang lebih lama, penelitian ini membagi menjadi 3 waktu yaitu Pra 1 erupsi dengan menggunakan data pasangan citra pada perekaman tanggal 10 Januari 2018 dengan 27 Februari 2018, Pra 2 erupsi dengan menggunakan pasangan citra pada perekaman tanggal 27 Februari dengan 10 Mei 2018, dan Pasca erupsi menggunakan pasangan citra pada perekaman tanggal 10 Mei 2018 dengan 22 Februari 2018. Hasil deformasi yang diamati dari pengolahan data Sentinel-1A Pra 1 erupsi dapat dilihat pada Gambar 4, Pra 2 erupsi dapat dilihat pada Gambar 5 dan Pasca erupsi dapat dilihat pada Gambar 6.

Wilayah penelitian ini adalah Gunung Merapi, Jawa Tengah (Gambar 3) dengan kondisi geografis Gunung Merapi di bagian puncak tidak pernah ditumbuhi vegetasi karena aktivitas yang tinggi. Jenis tumbuhan di bagian teratas bertipe alpina khas pegunungan Jawa, seperti Rhododendron dan edelweis jawa. Agak ke bawah terdapat hutan bambu dan tetumbuhan pegunungan tropika. Hutan hujan tropis pegunungan di lereng selatan Merapi merupakan tempat salah satu forma anggrek endemik Vanda tricolor 'Merapi' yang langka [9]. Jika di korelasikan dengan hasil dari interferogram setelah dilakukan proses Unwrapping, daerah yang mengandung vegetasi yang tinggi memiliki nilai koherensi yang rendah sedangkan daerah yang tidak memiliki vegetasi atau bervegetasi rendah memiliki nilai koherensi yang tinggi sebagai contoh pada bagian puncak Gunung Merapi. 


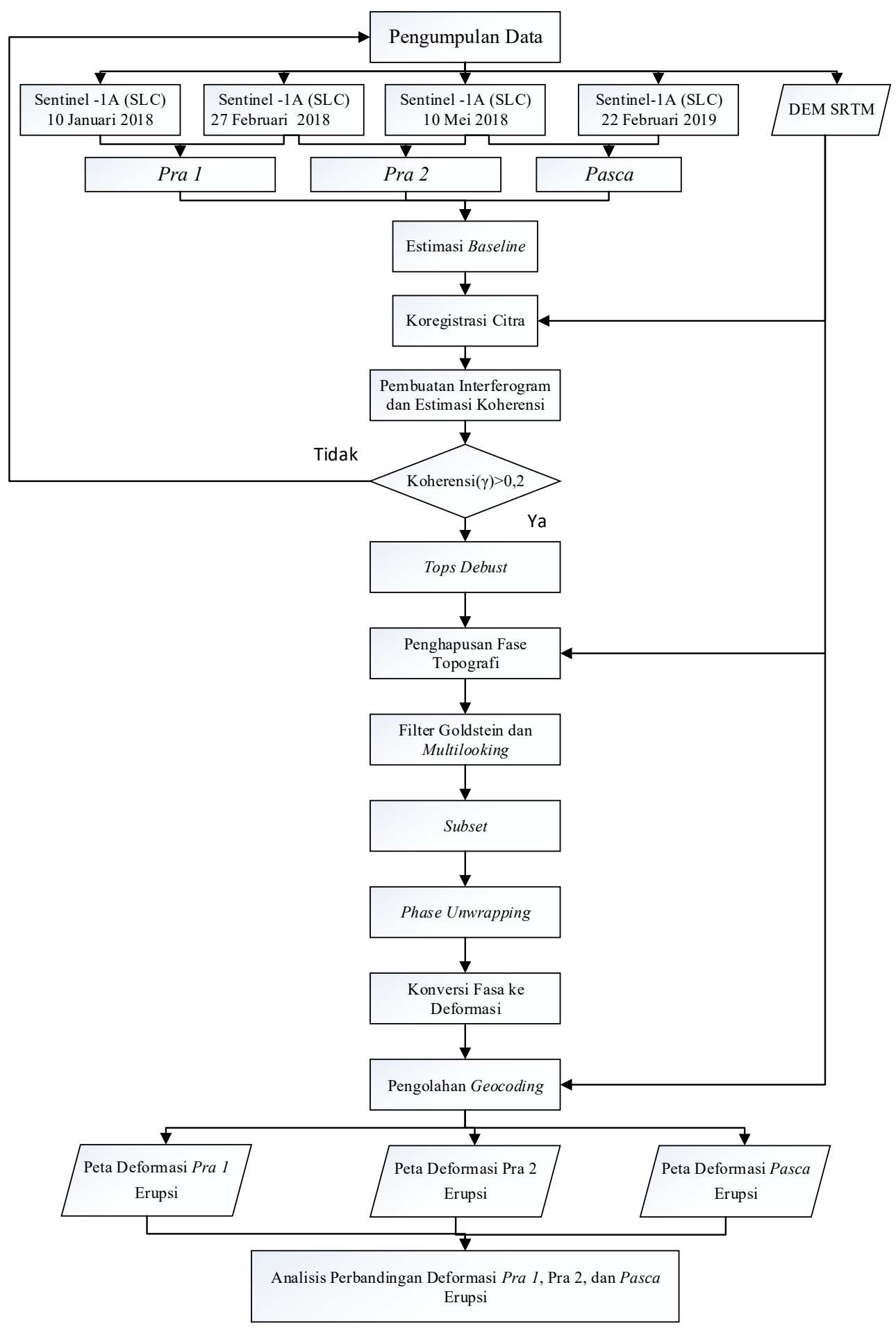

Gambar 1. Metodologi penelitian

Nilai koherensi menunjukkan kualitas dari hasil interferogram yang telah diolah, dengan cara mengestimasi phase noise yang terdapat pada citra. Nilai koherensi pada citra monitoring pra, saat dan pasca erupsi Gunung Merapi. Kisaran nilai koherensi 0-1 (Gambar 2A, 2B dan 2C). Nilai koherensi dengan nilai 1 menunjukkan pasangan citra tersebut memiliki korelasi yang baik, untuk penelitian ini penetapan standart nilai koherensi yaitu 0,2 . Rendahnya nilai koherensi pada citra interferogram dapat disebabkan karena ketidak cocokan sifat antara pasangan citra dikarenakan volume scattering. Selain 
itu nilai koherensi citra yang rendah disebabkan wilayah tersebut memiliki vegetasi yang rapat. Berdasarkan hasil pengolahan citra SAR pada psangan citra pra erupsi berada pada rentang nilai 0,007-0,99, sedangkan untuk pemgolahan citra SAR pada pasangan citra saat erupsi berada pada rentang nilai 0,001-0,99 dan untuk pengolahan citra SAR pada pasangan citra pra erupsi berada pada rentang nilai $0,001-0,98$. Rendahnya nilai koherensi ini menyebabkan banyaknya piksel yang kosong pada hasil pemrosesan Unwrapping.

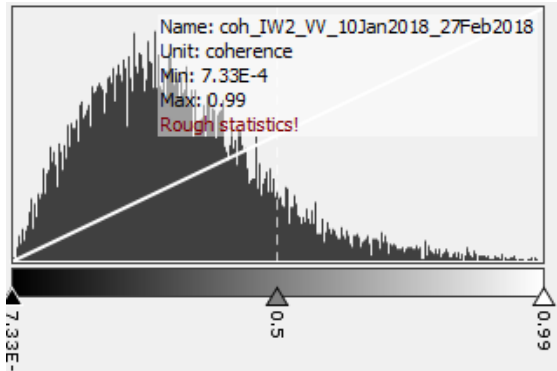

Gambar 2A. Hasil koherensi pada citra Pra erupsi.
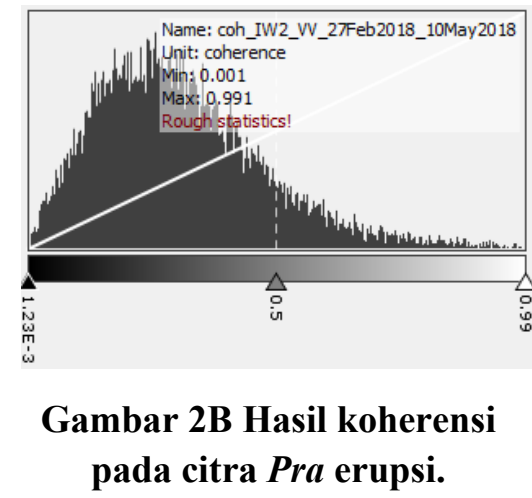

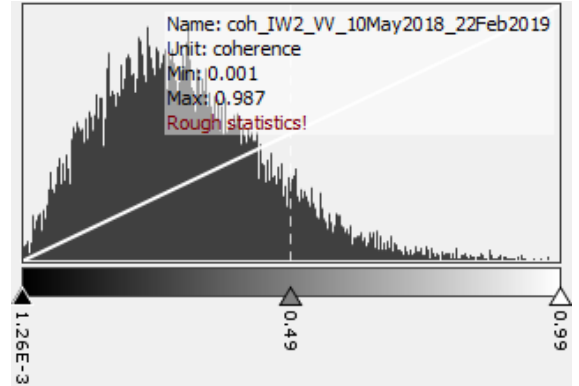

Gambar 2C. Hasil koherensi pada citra Pra erupsi.

Gunung Merapi juga memiliki kerakteristik relief yang beragam sehingga dapat menimbulkan efek layover dan foreshortening yang menyebabkan terjadinya wilayah kosong atau blank pada saat proses setelah unwrapping. Kondisi koherensi rendah menyebabkan adanya kekosongan pada interferogram, seperti hasil pada pra 1, yang dapat dilihat pada Gambar 3.

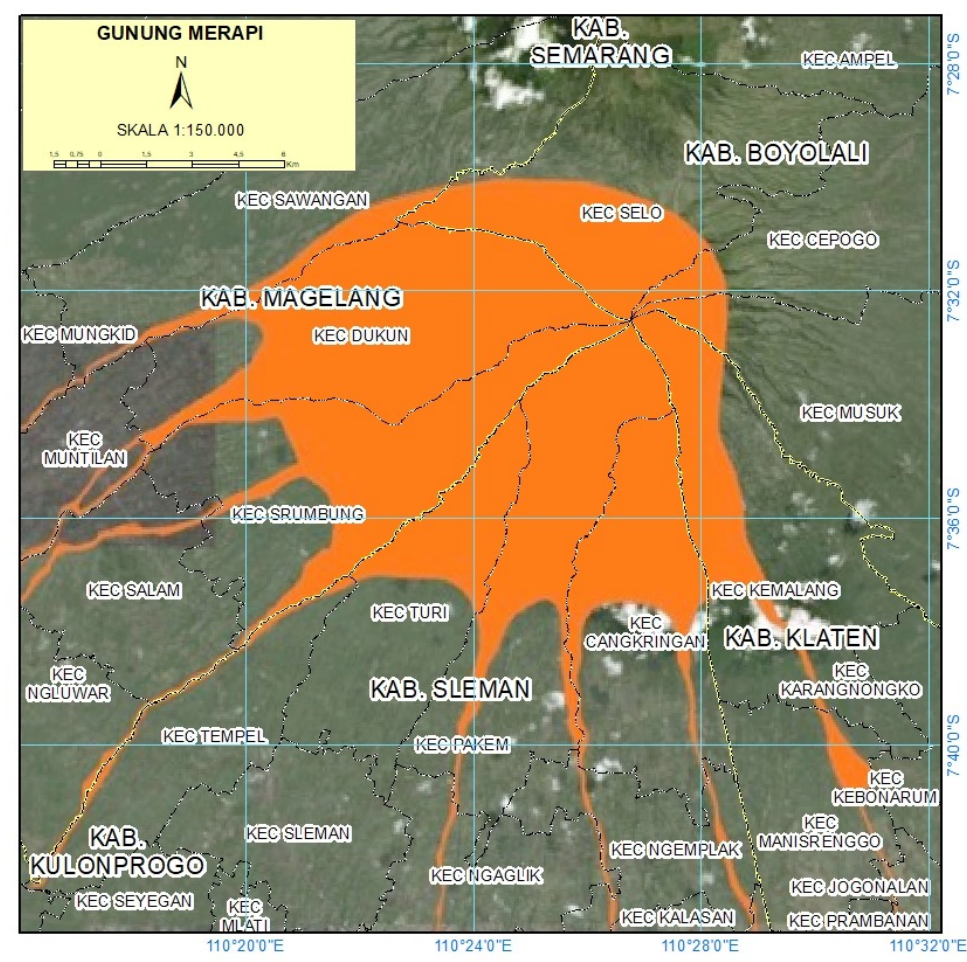

Gambar 3. Lokasi penelitian Gunung Merapi Jawa Tengah 


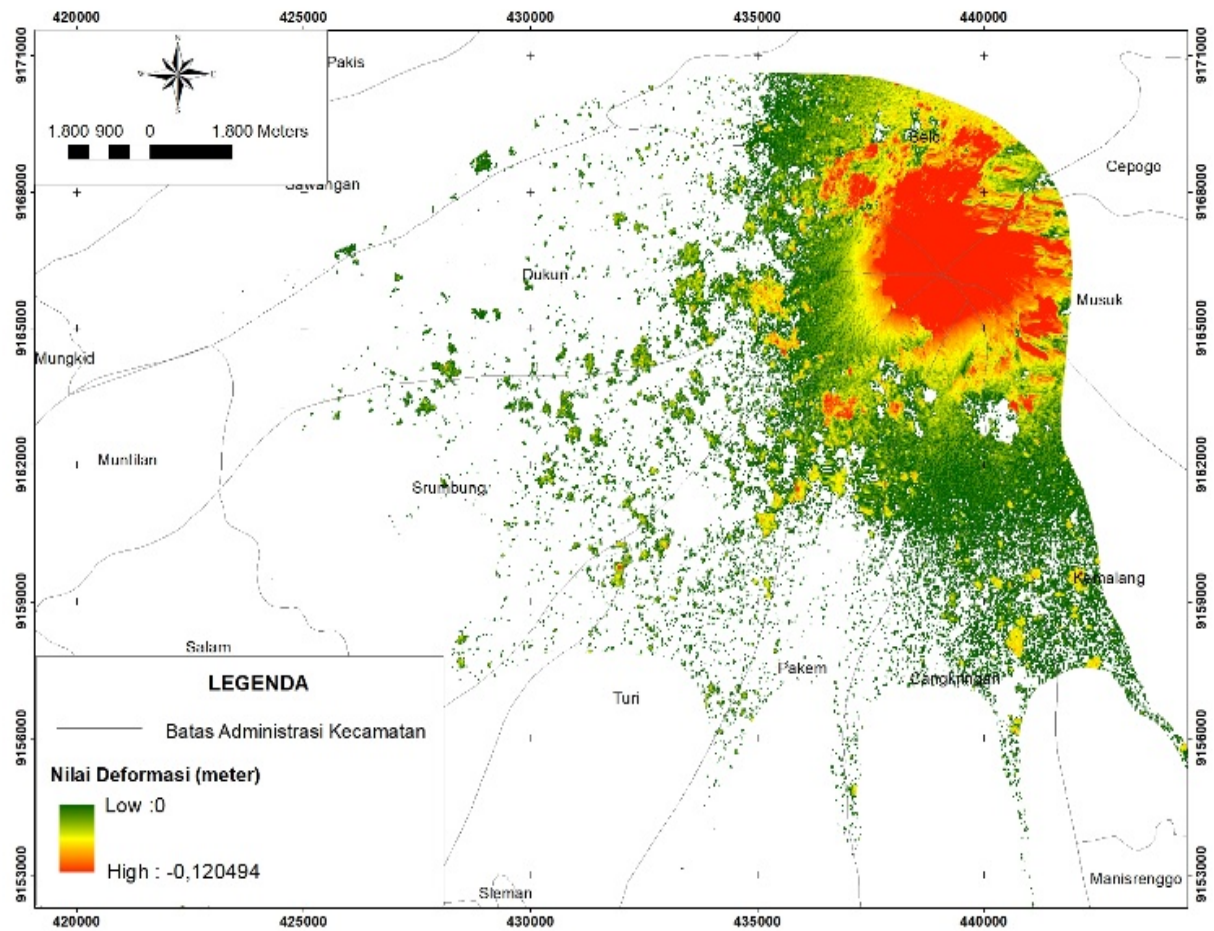

Gambar 4. Hasil deformasi Pra 1 erupsi Gunung Merapi Jawa Tengah

Hasil pengolahan pra 1 erupsi pada Gambar 4 mengalami deflasi sebesar -0,12 m.

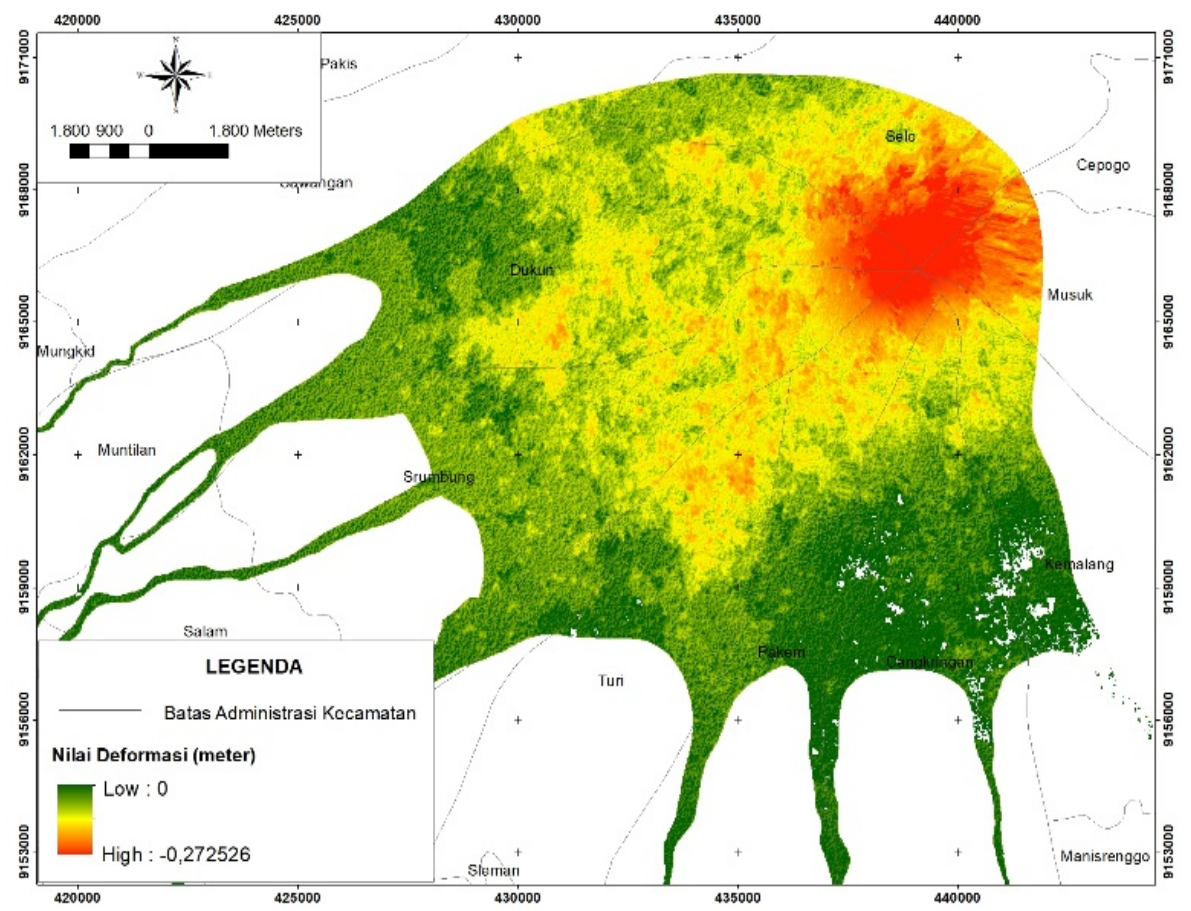

Gambar 5. Hasil deformasi Pra 2 erupsi Gunung Merapi Jawa Tengah

Hasil pengolahan pra 2 erupsi pada Gambar 5 mengalami deflasi sebesar -0,27 m. 


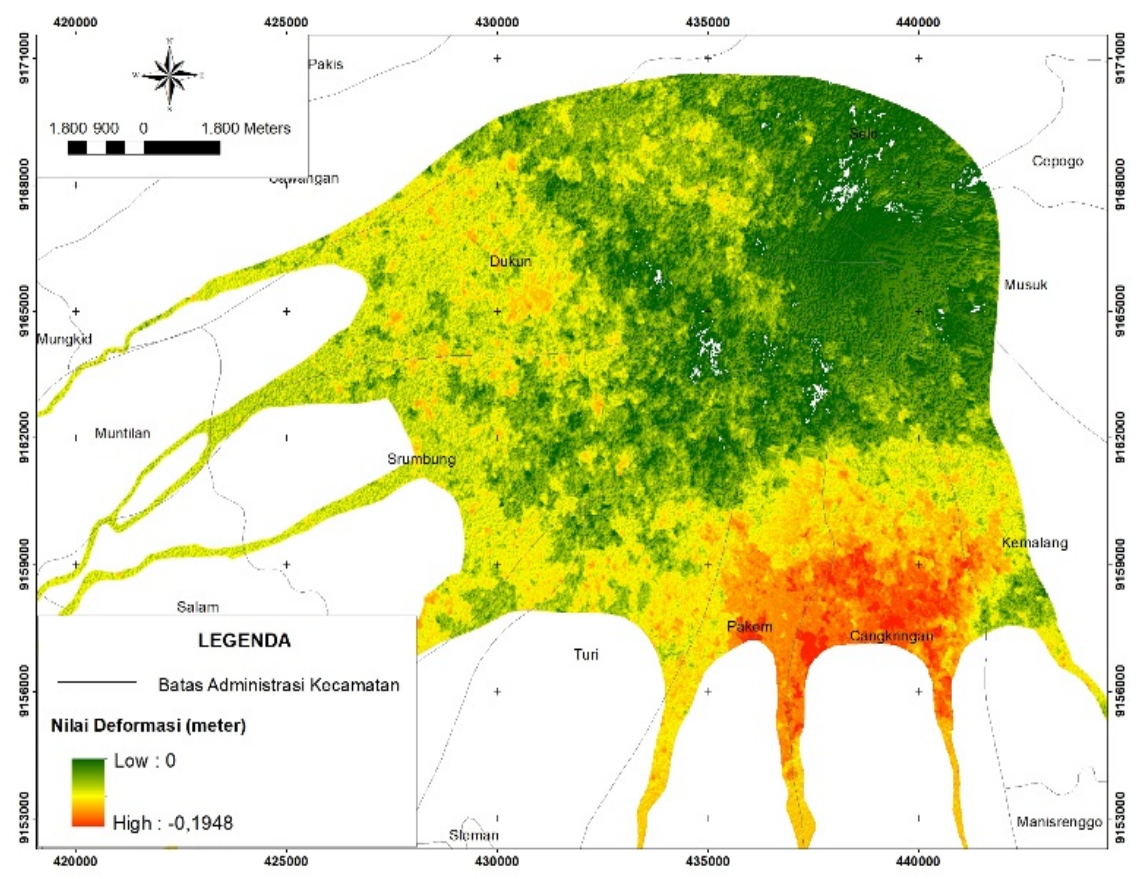

Gambar 6. Hasil deformasi pasca erupsi Gunung Merapi Jawa Tengah

Hasil pengolahan pasca erupsi pada Gambar 6 mengalami deflasi sebesar -0,194 m, sedangkan untuk hasil pengolahan pra 1, pra 2 dan pasca dapat dilihat pada Tabel 1.Untuk mengetahui deformasi pada masing-masing pasangan citra pra 1, pra 2 dan pasca erupsi maka dilakukan pembuatan cross section pada area kawah pada Gunung Merapi. Berikut ini besar deformasi muka tanah antara pasangan pra 1, pra 2 dan pasca. Posisi untuk garis sampel dapat dilihat pada Tabel 2 dan Gambar 7.

Tabel 1. Tabel deformasi Gunung Merapi Jawa Tengah

\begin{tabular}{|c|c|c|c|}
\hline \multirow{2}{*}{ Deformasi } & $\begin{array}{c}\text { Pra 1 (m) } \\
(10 \text { Jan 2018 -27 } \\
\text { Feb 2018) }\end{array}$ & $\begin{array}{c}\text { Pra 2 (m) } \\
(27 \text { Feb 2018-10 } \\
\text { Mei 2018) }\end{array}$ & $\begin{array}{c}\text { Pasca (m) } \\
(10 \text { Mei 2018 - 22 } \\
\text { Feb 2019) }\end{array}$ \\
\hline Nilai Deformasi & $-0,12$ & $-0,272$ & $-0,1947$ \\
\hline
\end{tabular}

Tabel 2. Koordinat garis sampel

\begin{tabular}{|c|c|}
\hline Posisi & Koordinat (m) \\
\hline A & 438128,$007 ; 9167580,329$ \\
\hline B & 439832,$809 ; 9164186,247$ \\
\hline
\end{tabular}




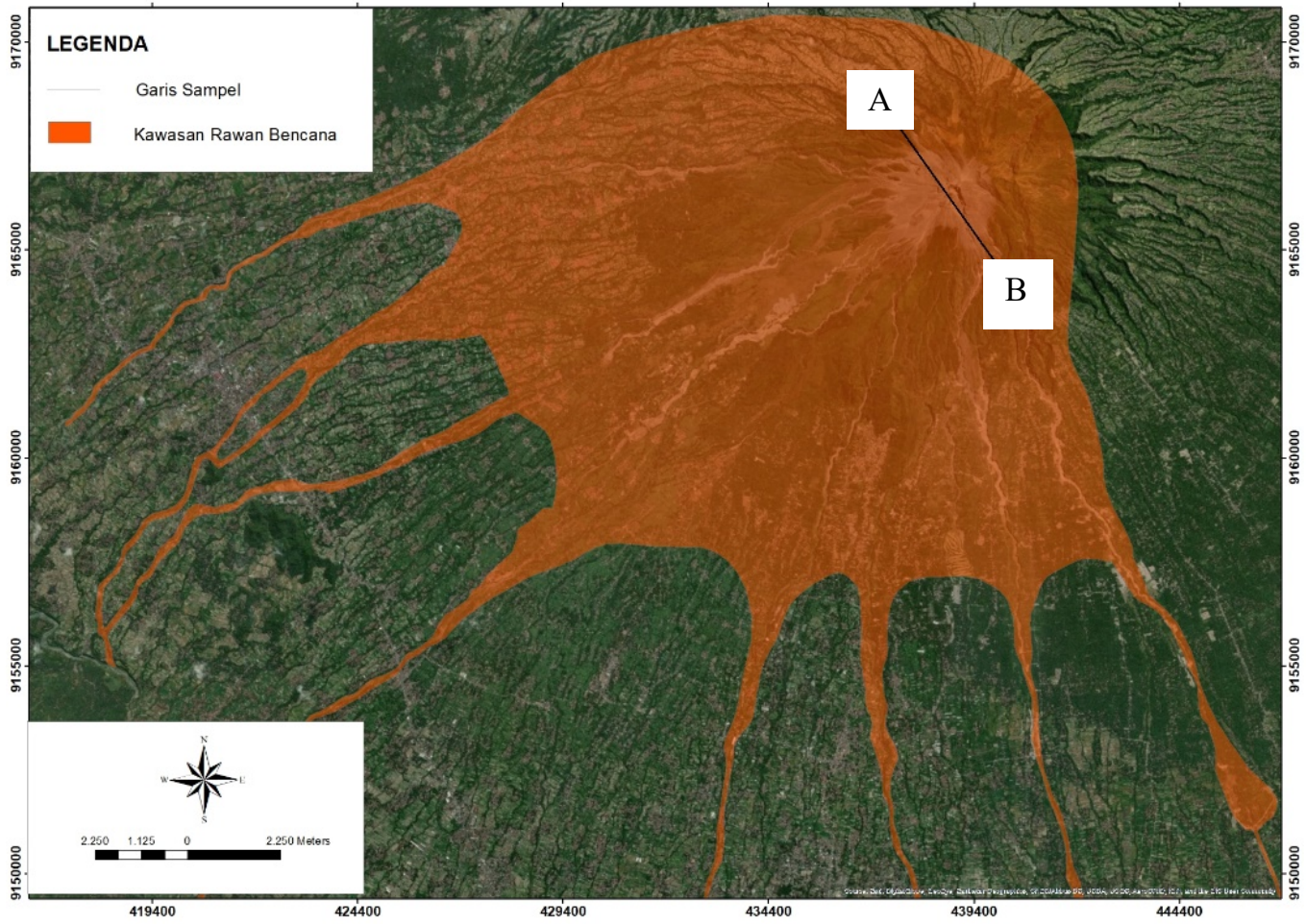

Gambar 7. Gambaran posisi garis sampel

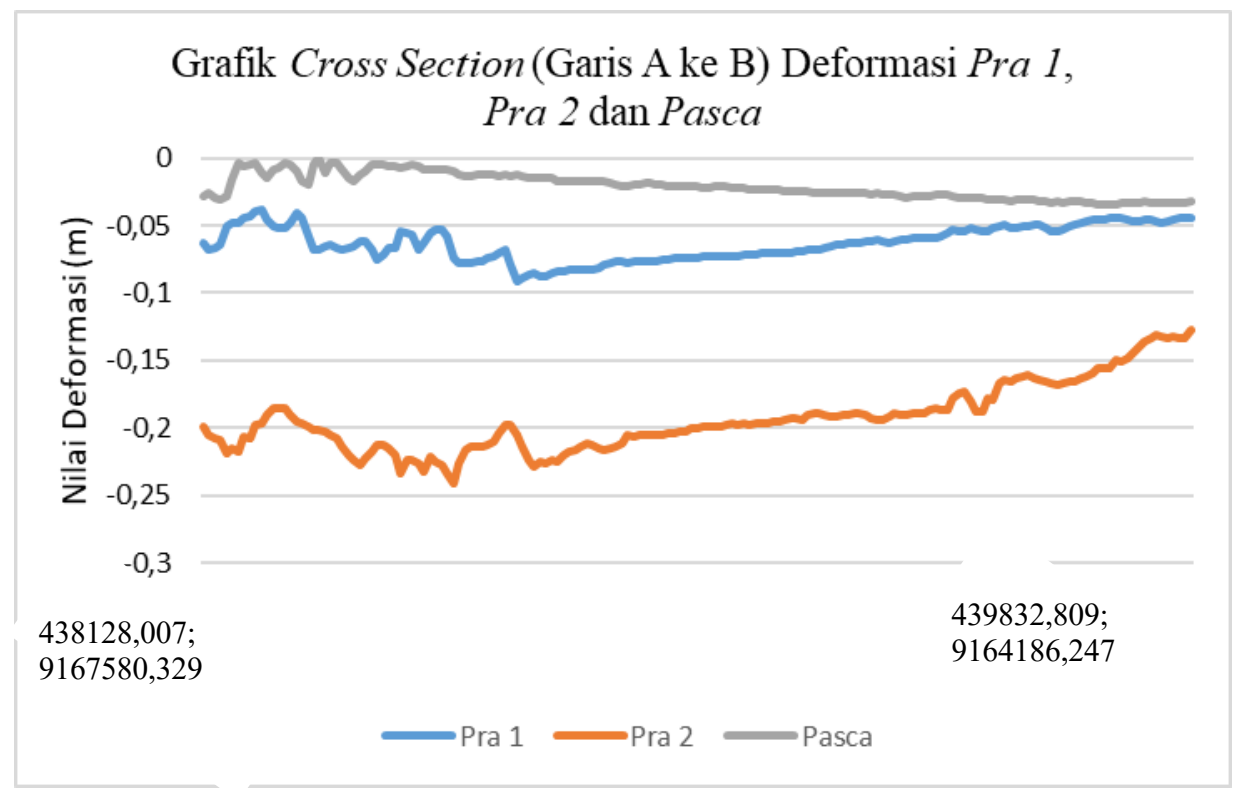

Gambar 8. Grafik Cross Section deformasi Pra 1, Pra 2 Dan Pasca

Hasil dari pengambilan garis sampel (cross section) yang terdapat pada kawah Gunung Merapi menunjukkan citra pra 1 mengalami deflasi dengan rentang antara 0,0908 m sampai dengan $0,0378 \mathrm{~m}$, sedangkan pada citra pra 2 mengalami deflasi dengan rentang antara $0,2413 \mathrm{~m}$ sampai dengan 0,1271 $\mathrm{m}$ dan pada citra pasca mengalami deflasi dengan rentang antara $0,0341 \mathrm{~m}$ sampai dengan $0,0001 \mathrm{~m}$.

Berdasarkan grafik cross section (Gambar 8) garis sampel pra 1 ke pra 2 mengalami deflasi dengan rentang antara $0,1505 \mathrm{~m}$ sampai dengan $0,0893 \mathrm{~m}$, sedangkan pada pra 2 dengan pasca erupsi mengalami inflasi dengan rentang antara 0,2072 m sampai dengan $0,127 \mathrm{~m}$. 
Dari hasil penelitian tersebut, hasil deformasi pra 1, pra 2 dan hasil evaluasi pada kubah Gunung Merapi antara pra 1 dan pra 2 mengalami deflasi dikarenakan, menurut humainda (2019) pada bulan April 2018 Gunung Merapi sudah mengalami 1 kali gempa vulkanik dan 40 kali gempa guguran, dan pada tanggal 11 Mei 2018 mengalami erupsi freatik. Kemudian hasil deformasi pada pasca erupsi mengalami deflasi dikarenakan menurut [10] pada tanggal 21 Mei 2018 terjadi letusan yang tersusun dari komponen magmatik, sedangkan terjadi inflasi pada hasil evaluasi kubah Gunung Merapi antara pra 2 ke pasca dikarenakan, menurut [10] sepanjang tahun 2018 dan awal 2019 Gunung Merapi memulai fase pertumbuhan kubah lava.

\section{KESIMPULAN}

Pada penelitian ini, erupsi dari kondisi pra 1, Pra 2 dan pasca erupsi semuanya mengalami deflasi dikarenakan beberapa kondisi yang dapat diuraikan sebagai berikut:

1. Pra 1 menggunakan data pasangan citra pada perekaman tanggal 10 Januari 2018 dengan 27 Februari 2018. Erupsi mengalami deflasi sebesar 0,12 m dikarenakan telah terjadi guguran awan panas sebanyak 23 kali sejak 29 Januari 2018.

2. Pra 2 erupsi dengan menggunakan pasangan citra pada perekaman tanggal 27 Februari dengan 10 Mei 2018. Erupsi mengalami deflasi sebesar 0,27 m dikarenakan pada bulan April 2018 Gunung Merapi sudah mengalami 1 kali gempa vulkanik dan 40 kali gempa guguran deformasi yang terbesar terjadi pada puncak Gunung Merapi

3. Pasca erupsi menggunakan pasangan citra pada perekaman tanggal 10 Mei 2018 dengan 22 Februari 2018. Pasca erupsi mengalami deflasi sebesar 0,194 $\mathrm{m}$ dikarenakan adanya erupsi freatik yang terjadi pada tanggal 11 Mei 2018.

4. Garis sampel pra 1 ke pra 2 mengalami deflasi dengan rentang antara 0,1505 m sampai dengan $0,0893 \mathrm{~m}$, sedangkan pada pra 2 dengan pasca erupsi mengalami inflasi dengan rentang antara $0,2072 \mathrm{~m}$ sampai dengan $0,127 \mathrm{~m}$.

\section{UCAPAN TERIMA KASIH}

Penulis mengucapkan terima kasih kepada Balai Penyelidikan dan Pengambangan Teknologi Kebencanaan Geologi (BPPTKG) Yogyakarta yang telah memberikan izin untuk melakukan penelitian.

\section{DAFTAR PUSTAKA}

[1] Surono. (2012). Kompas. Retrieved from Indonesia memiliki 127 Gunung api aktif.: http://lipi.go.id/berita/single/Indonesia-Miliki-127-Gunung-Api-Aktif/7448.

[2] Abidin, dkk. (2002). Studi Defromasi Gunung api Batur dengan Metode Survey GPS. Jurnal Survey dan Geodesi, Vol.XII, No.3.

[3] Kuang. (1996). Geodetic Network Analysis and Optimal Design : Concept and Application. Ann Arbor Pr Inc.

[4] Cumming, I. (2005). Digital Processing of Synthetic Arpeture Radar Data. Artech House Remote Sensing Library.

[5] Barra, A., Solari, L., Béjar-Pizarro, M., Monserrat, O., Bianchini, S., Herrera, G., Crosetto, M., Sarro, R., González-Alonso, E., Mateos, R.M., Ligüerzana, S., dkk. (2017). A Methodology to 
Detect and Update Active Deformation Areas Based on Sentinel-1 SAR Image. Remote Sensing MDPI , 9, 1002.

[6] ESA. (2012). Sentinel-1A. Retrieved from.https://sentinels.copernicus.eu/web/sentinel/home.

[7] Febriyanti. (2017). Analisis Deformasi Gunung Raung menggunakan Teknologi Differential Interferometry Synthetic Radar (DInSAR). Jurnal Teknik ITS, 6(2), DOI: $10.12962 / \mathrm{j} 23373539 . v 6 \mathrm{i} 2.25018$.

[8] Fárová, K., Jelének, J., Kopa cková-Strnadová, V., Kycl, P. (2019). Comparing DInSAR and PSI Techniques Employed to Sentinel-1 Data to Monitor Highway Stability: A Case Study of a Massive Dobkovi cky Landslide, Czech Republic. Remote Sensing MDPI, 11, 2670.

[9] Metusala. (2006, Juli 20). Geografis Gunung Merapi. Retrieved from http://anggrek.org/melirikkonservasi-anggrek-vanda-tricolor-di-merapi-2.html

[10] Humaida, H. (2019, Februari 21, Kamis). Lima Fase Merapi Sejak 2010. (W. Suryana, Interviewer) 